ISSN : 1412-7601

Volume 4, No.1 Maret 2018

http://www.ekonobis.unram.ac.id

EKONOBIS

\title{
PELUANG DAN TANTANGAN LEMBAGA KEUANGAN MIKRO SYARIAH (BMT) DALAM MENGURANGI KEMISKINAN DI NUSA TENGGARA BARAT
}

\section{Iman Suriadi}

Universitas Mataram

ARTICLE INFO $\quad$ Received : 2 Februari 2018; Accepted: 4 Maret 2018; Published: Maret 2018

Keywords :

Sharia Microfinance

Institution (BMT), SWOT

Analysis, West Nusa

Tenggara

ABSTRACT : The objectives of this study were (a) to analyze the opportunities and challenges of Islamic microfinance institutions (BMT) in West Nusa Tenggara (b) to analyze the development strategy of Islamic microfinance institutions (BMT) in West Nusa Tenggara. The type of this research is descriptive research. The analysis technique used in this research is SWOT Analysis (Strength, Weakness, Opportunity, Treath). The results showed that the supporting factors can be seen from the strengths and opportunities of Islamic microfinance institutions (BMT) in West Nusa Tenggara that must have a strategic location and community empowerment by Islamic microfinance institutions (BMT), the inhibiting factor can be seen from the weaknesses and threats posed by Islamic microfinance institutions (BMTs) in West Nusa Tenggara, namely the lack of socialization from Islamic banks working on micro markets, the policy strategy of Islamic microfinance institutions (BMT) in the face of threats, namely Islamic microfinance institutions (BMT) in Nusa Tenggara The West must continuously develop itself creatively, innovatively and always have improvements in service to customers of Islamic microfinance institutions (BMT)

Kata Kunci :

Lembaga Keuangan Mikro

Syariah (BMT), Analisis SWOT, Nusa Tenggara Barat
ABSTRAK : Tujuan penelitian ini adalah (a) Untuk Menganalisis peluang dan tantangan lembaga keuangan mikro syariah (BMT) di Nusa Tenggara Barat(b) Untuk menganalisis Strategi pengembangan lembaga keuangan mikro syariah (BMT) di Nusa Tenggara Barat. Jenis dari penelitian ini adalah penelitian deskriptif, Teknik analisis yang digunakan dalam penelitian ini adalah Analisis SWOT (Strength, Weakness, Opportunity, Treath). Hasil penelitian menunjukkan bahwa Faktor pendukung dapat dilihat dari kekuatan dan peluang yang dimiliki oleh lembaga keuangan mikro syariah (BMT) di Nusa Tenggara Barat yang harus memiliki lokasi yang strategis dan pemberdayaan masyarakat oleh lembaga keuangan mikro syariah (BMT), Faktor Penghambat dapat dilihat dari kelemahan dan ancaman yang dimiliki oleh lembaga keuangan mikro syariah (BMT) di Nusa Tenggara Barat yaitu kurangnya sosialisasi dari Bank syariah yg menggarap pasar mikro, Strategi kebijakan lembaga keuangan mikro syariah (BMT) dalam menghadapi ancaman yaitu lembaga keuangan mikro syariah (BMT) di Nusa Tenggara Barat harus terus menerus mengembangkan diri secara kreatif, inovatif dan selalu memiliki perbaikan dalam pelayanan kepada nasabah lembaga keuangan mikro syariah (BMT)

Corresponding Author:

Alamat : Program Studi Ekonomi Pembangunan, Fakultas Ekonomi dan Bisnis, Universitas Mataram, Jln. Majapahit No. 62 Mataram.

e-mail: irwansuriadi@gmail.com 


\section{PENDAHULUAN}

\section{Latar Belakang}

Di dalam suatu perekonomian kemiskinan merupakan masalah yang sangat mendasar untuk di pecahkan dengan berbagai cara dan startegi. Salah satunya dengan pemberdayaan masyarakat kecil melalui pemberian akses modal untuk digunakan dalam kegiatan produktif (berdagang), terutama masyarakat yang berada pada sektor informal yang selama ini terpinggirkan. Sektor informal merupakan salah satu penyangga perekonomian nasional yang memiliki peranan yang sangat besar di dalam mengurangi kemiskinan. Besarnya peranan sektor informal di dalam aktivitas ekonomi diseluruh negara berkembang dan keterpurukan ekonomi dinegara berkembang desebabkan oleh ketiadaan modal (Hernande de Soto,2001). Di mana asset di negara berkembang tidak mampu menjadi modal kerja karena tersandung masalah kepemilikan (property right) dan belum efektifnya lembaga keuangan mikro yang langsung melayani dan menjangkau sektor usaha mikro, kecil dan sektor informal yang secara memadai mampu memberikan alternatif pelayanan baik simpan-pinjam maupun pembiayaan yg sesuai dengan kondisi sosial kultural serta kebutuhan ekonomi masyarakat.

Tabel 1. Jumlah Garis Kemiskinan (Rp/Kapita/Bulan)

\begin{tabular}{|l|l|l|l|l|l|l|}
\hline \multirow{2}{*}{ Daerah } & \multicolumn{5}{|c|}{ Garis Kemiskinan (Rp/Kapita/BIn) } \\
\cline { 2 - 7 } & \multicolumn{2}{|c|}{ Makanan } & \multicolumn{2}{c|}{$\begin{array}{c}\text { Bukan } \\
\text { Makanan }\end{array}$} & \multicolumn{2}{c|}{ Jumlah } \\
\cline { 2 - 7 } & $\mathbf{2 0 1 5}$ & $\mathbf{2 0 1 6}$ & $\mathbf{2 0 1 5}$ & $\mathbf{2 0 1 6}$ & $\mathbf{2 0 1 5}$ & $\mathbf{2 0 1 6}$ \\
\hline \multirow{2}{*}{ Perkotaan } & 238. & 251. & 89. & 91. & 328. & 343. \\
& 797 & 734 & 328 & 846 & 125 & 580 \\
\hline \multirow{2}{*}{ Pedesaan } & 232. & 249. & 71. & 77. & 304. & 326. \\
& 281 & 490 & 786 & 166 & 068 & 656 \\
\hline Perkotaan & 235. & 250. & 79 & 83 & 314. & 333 \\
+Pedesaan & 036 & 371 & .202 & .624 & 238 & .996 \\
\hline
\end{tabular}

Sumber ; Badan Pusat Statitistik NTB
Masih tingginya tingkat kemiskinan di Nusa Tenggara Barat ini diakibatkan oleh kurangnya perhatian pemerintah dalam mengembangkan dan mensinergikan lembaga keuangan mikro yang dapat menjangkau masyarakat di tingkat paling bawah (masyarakat ekonomi lemah) terutama pada akses permodalan untuk menjalankan usaha yang sedang atau akan dirintis untuk mendapatkan penghasilan.

Daerah Nusa Tenggara Barat memiliki jumlah penduduk dengan mayoritas muslim yang bekerja diberbagai sector, terutama sector informal seperti bekerja disektor pertanian, perdagangan dan jasa. Permasalahan yang sering muncul dari para pekerja informal terutama pedagang adalah akses permodalan dari perbankan yang sangat kurang, belum lagi persyaratan perbankan yang terkadang memberatkan para debitur kecil seperti jaminan, platfon pembiayaan yang rumit sampai dengan proses administrasi yang sangat memberatkan debitur kecil tersebut.

Peranan sector informal di daerah Nusa Tenggara Barat seperti para pedagang kecil, pedagang kaki lima dan para penjual keliling sangat besar, oleh karena itu dibutuhkan akses permodalan yang cukup kuat agar keberlangsungan usaha mereka akan tercapai. Pemerintah dapat memberikan kesempatan kepada lembaga keuangan yang akses permodalannya kuat seperti Baitul Mal Wattamwil (BMT). Lembaga keuangan mikro ini memang masih kurang dikenal oleh masyarakat terutama masyarakat Nusa Tenggara Barat karena lembaga keuangan mikro ini belum banyak berdiri di daerah Nusa Tenggara Barat ini. Lembaga ini dapat memberikan pinjaman kepada debitur dengan pinjaman yang sangat rendah mulai dari Rp 50.000 - Rp 30.000.000, bank besar atau lembaga keuangan besar kadangkala tidak mau memberikan pinjaman yang rendah seperti yang 
dilakukan Baitul Mal Wattamwil (BMT) karena keuntungan yang diharapkan dari pinjaman tersebut kecil.

Dengan adanya kemudahan akses permodalan yang diberikan oleh Baitul Mal Wattamwil (BMT) dapat menjadi solusi untuk mengurangi kemiskinan di Nusa Tenggara Barat melalui pemberdayaan masyarakat terutama para pedagang yang bergerak di sector informal dengan pemberian kredit lunak yang diharapkan dapat membantu para pedagang dalam rangka keberlangsungan usaha mereka. Oleh karena itu diperlukan penelitian dengan judul "Pengembangan Lembaga Keuangan Mikro Syariah (Baitul Mal Wattamwil) dalam mengurangi kemiskinan di Nusa Tenggara Barat"

Perumusan Masalah

1. Bagaimanakah peluang dan tantangan lembaga keuangan mikro syariah (BMT) di Nusa Tenggara Barat

2. Bagaimanakah Strategi pengembangan lembaga keuangan mikro syariah (BMT) di Nusa Tenggara Barat

\section{Tujuan Penelitian}

1. Untuk Menganalisis peluang dan tantangan lembaga keuangan mikro syariah (BMT) di Nusa Tenggara Barat

2. Untuk menganalisis Strategi pengembangan lembaga keuangan mikro syariah (BMT) di Nusa Tenggara Barat

\section{Manfaat penelitian}

1. Membantu pemerintah dalam menentukan strategi dan kebijakan berkaitan dengan pengembangan lembaga keuangan mikro syariah.

2. Membantu masyarakat dalam mengakses permodalan dengan adanya Baitul Mal Wattamwil (BMT)

3. Seara teoritis sebagai tambahan refrensi bagi pihak-pihak yang ingin melakukan penelitian lebih lanjut mengenai Lembaga Keuangan Mikro Syariah seperti Baitul Mal Wattamwil (BMT).

\section{TINJAUAN PUSTAKA}

\section{Penelitian Terdahulu}

Penelitian yang dilakukan oleh Hendayana dan Bustaman (2007)mengkaji tentang fenomena lembaga keuangan mikro dalam persfektif pembangunan ekonomi pedesaan dengan menggunakan metode group interview dan individual indept interview, hasilnya adalah pengembangan lembaga keuangan mikro sangat tergantung dari kemampuan lembaga keuangan mikro dalam memaksimalkan peluang dan kekuatan serta meminimalisir kelemahan dan ancaman yang muncul, lembaga keuangan mikro dijadikan salah satu instrumen kebijakan pemerintah dalam upaya meningkatkan produktivitas pertanian menuju peningkatan pendapatan dan kesejahteraan petani yang sesuai dengan karakteristik kebutuhan permodalan petani, dan untuk dapat mengoptimalkan lembaga keuangan mikro sebagai instrumen kebijakan pemerintah yang efektif dan efisien, maka diperlukan pendekatan partisipatif dan penguatan sumber daya manusia lembaga keuangan mikro.

Wiloejo Wirjo Wiyono(2005) meneliti tentang pemberdayaan lembaga keuangan mikro sebagai salah satu pilar sistem keuangan nasional : upaya konkrit memutus mata rantai kemiskinan, Hasil dari penelitiannya adalah salah satu upaya yang dilakukan dalam mengentaskan kemiskinan adalah dengan memperluas akses UMKM dalam mendapatkan fasilitas permodalan terutama dari lembaga keuangan mikro, lembaga keuangan mikro ternyata dapat memberikan berbagai jenis pembiayaan yang dapat dijadikan alternatif dalam pembiayaan yang cukup potensial, dan upaya yang dapat dilakukan dalam mengembangkan lembaga keuangan mikro adalah dengan membuat 
payung hukum dalam bentuk undangundang lembaga keuangan mikro.

Nurkholis (2009) meneliti tentang kontribusi lembaga keuangan mikro di dalam meningkatkan kesejahteraan di indonesia dengan menggunakan metode kualitatif dalam analisisnya, hasil penelitiaanya adalah lembaga keuangan islam seperti Baitul maal wattamwil (BMT) memiliki peran yang sangat penting dalam kegiatan ekonomi dalam meningkatkan pendapatan masyarakat, mengurangi kemiskinan dan meningkatkan kesejahteraan sosial seperti yang dilakukan oleh BMT Dana syariah sebagai salah satu lembaga yang memiliki peranan yang sangat penting dalam pembiayaan usaha mikro kecil.

Syeda Shehrbano Kazim dan Syed Eisar Haider (2012) meneliti tentang model lembaga keuangan mikro di Pakistan dengan menggunakan Waqf based model, hasil penelitiannya adalah model lembaga keuangan mikro yang digunakan dalam mengurangi kemiskinan bagi masyarakat miskin adalah pinjaman dalam bentuk Qardhasan, yaitu pemberian pinjaman sukarela dari hasil keuntungan lembaga keuangan dan pinjaman dalam bentuk takaful (tolong menolong).

Asyraf Wajdi Dusuki (2007) melakukan penelitian yang berkaitan dengan bank bagi orang miskin, model yang digunakan adalah special purpose vehicle (SPV) sebagai chaneling bagi orang miskin hasil penelitiannya adalah transaksi keuangan di dalam islam ditujukan untuk mengurangi kemiskinan, keadilan sosial dan untuk distribusi kekayaan yang adil dan merata. Lembaga keuangan islam perlu melakukan inovasi dimasa yang akan datang dalam peranannya sebagai lembaga intermediasi, meningkatkan kemampuan dan kapasitas sumberdaya manusia

\section{Landasan Teori}

\section{Sistem Ekonomi Islam}

Sistem ekonomi islam merupakan sistem ekonomi yang berlandaskan pada prinsipprinsip yang terkandung di dalam Alqur'an dan Al-hadis.

Nilai-nilai yang terkandung di dalam sistem ekonomi islam terdiri dari (Antonio,2001;30-17):

1.Perekonomian masyarakat luas yang mengacu pada norma-norma islami

Terdapat banyak ayat di dalam Al-Qur'an yang menyerukan pada penggunaan kerangka kerja perekonomian islam seperti yang terkandung pada surat AlBaqarah ayat 60 yang artinya "Makan dan minumlah dari rezeki (yang diberikan) Allah SWT dan janganlah berkeliaran di muka bumi ini dengan berbuat kerusakan".

Dari ayat diatas dapat dipahami bahwa islam mendorong penganutnya untuk menikmati karunia yang telah diberikan oleh Allah SWT, dimana karunia tersebut harus didayagunakan untuk meningkatkan pertumbuhan baik materi maupun nonmateri.

1. Keadilan dan persaudaraan menyeluruh

Islam bertujuan untuk membentuk masyarakat dengan tatanan sosial yang solid, di mana setiap individu diikat oleh persaudaraan dan kasih sayang bagai satu keluarga. Hal ini terlihat di dalam surat Al-Hujurat ayat 13 artinya "Hai Manusia, Sesungguhnya kami menciptakan kamu dari seorang lakilaki dan seorang perempuan serta menjadikan kamu berbangsa-bangsa dan bersuku-suku agar kamu saling mengenal. Sesungguhnya orang yang paling mulia diantara kamu disisi Allah SWT adalah orang yang paling bertaqwa. Sesungguhnya Allah SWT maha mengetahui lagi maha mengenal".

Islam selalu mengajarkan keadilan dan memberi peringatan kepada orang 
yang tidak berlaku adil seperti yang tercantum di dalam Hadis yang diriwayatkan oleh Imam Ahmad yang artinya "Wahai manusia, takutlah akan kezaliman (ketidakadilan) sebab sesungguhnya dia akan menjadi kegelapan pada hari pembalasan nanti."

2. Keadilan Distribusi Pendapatan

Adanya kesenjangan pendapatan dan kekayaan alam yang ada didalam masyarakat berlawanan dengan semangat serta komitmen islam terhadap persaudaraan dan keadilan sosial ekonomi. Kesenjangan tersebut harus diatasi dengan menggunakan cara-cara yang ditekankan islam dengan cara :

a. Menghapuskan monopoli, kecuali oleh pemerintah untuk bidangbidang tertentu.

b. Menjamin hak dan kesempatan semua pihak untuk aktif di dalam proses ekonomi

c. Menjamin pemenuhan kebutuhan dasar hidup setiap anggota masyarakat

3. Kebebasan individu dalam konteks kesejahteraan sosial

Islam mengakui pandangan universal bahwa kebebasan individu dibatasioleh kebebasan individu orang lain, seperti prinsip-prinsip dibawah ini ;

a. Kepentingan masyarakat yang lebih luas harus didahulukan dari kepentingan individu

b. Melepas kesulitan harus diprioritaskan dibanding memberi manfaat

c. Kerugian yang lebih besar tidak dapat diterima untuk menghilangkan yang lebih kecil.

\section{Lembaga Keuangan di dalam Islam}

Lembaga keuangan memang tidak disebutkan secara eksplisit di dalam AlQuran, tetapi jika yang dimaksud lembaga itu sesuatu yang memiliki unsur-unsur seperti struktur, manajemen, fungsi serta hak dan kewajiban, maka semua lembaga tersebut disebutkan secara jelas seperti kata Ummat (Kelompok masyarakat), muluk (pemerintah), balad (negeri), suq (pasar)yang mengindikasikan fungsi dan perannya sama dengan lembaga yang ada saat ini (Muhammad,2002;21).

Sejarah lembaga keuangan dalam sejarah islam

1. Lembaga keuangan di zaman Rasulullah

Lembaga keuangan yang didirikan pertamakali adalah baitul mal (lembaga penyimpanan) dengan melakukan operasional penerimaan pendapatan dan pembelanjaan yang transparan yang bertujuan untuk mencapai welfare oriented.

Lembaga lain yang juga didirikan oleh Rasulullah adalah Wilayatul Hisbah yang berfungsi sebagai pengawasan atau kontrol oleh negara yang dipegang langsung oleh rasulullah. Selain itu lembaga ini juga menjadi pilar infrastruktur yang menjadi bingkai bagi aktivitas ekonomi dan muamalat.

2. Lembaga keuangan di zaman Khulafa Rasyidin

Lembaga keuangan di zaman Khulafa Rasyidin meneruskan lembaga keuangan yang dibangun di jaman rasulullah, di mana baitul mal semakin mapan bentuknya. Pada masa Umar Bin Khatab memperluas basis zakat dan sumber pendapatan lain serta membuat kebijakan dengan memberlakukan kuota kepada para pedagang yang datang dari Persia dan Romawi, karena kedua negara tersebut memberlakukan hal yang sama kepada para pedagang di Madinah. Kebijakan Umar bin khatab diteruskan oleh Usman bin Affan dan Ali bin Abi Thalib dengan memaksimalkan pendapatan dan penerimaan dari baitul mal yang berfungsi sebagai kebijakan fiskal.

Baitul Maal Wattamwil (BMT) 
Baitul Maal Wattamwil (BMT) berasal dari dua istilah, dimana baitul maal mengarah pada usaha-usaha pengumpulan dan penyaluran dana yang bersifat non profit seperti zakat, infaq dan sadaqah sedangkan baitut tamwil sebagai usaha pengumpulan dan penyaluran dana yang bersifat komersial. Usaha-usaha tersebut menjadi bagian yang tidak terpisahkan dari Baitul Maal Wattamwil (BMT) sebagai lembaga pendukung kegiatan ekonomi masyarakat kecil yang berlandaskan syariah (Sudarsono,2008;303).

Menurut Ridwan $(2004,126)$ Baitul Maal Wattamwil (BMT) merupakan organisasi bisnis yang juga berperan sosial. Sebagai lembaga sosial Baitul Maal Wattamwil (BMT) memiliki fungsi seperti pengumpulan dana zakat, infaq, sadaqah dan wakaf dan sumber dana sosial lainnya. Sebagai lembaga bisnis Baitul Maal Wattamwil (BMT) lebih mengembangkan usahanya pada sektor keuangan seperti simpan pinjam yang menghimpun dana dari anggota dan calon anggota (nasabah) serta menyalurkannya kepada sektor ekonomi yang halal dan menguntungkan.

\section{Fungsi dan Peran Baitul Maal Wattamwil (BMT)}

Menurut Ridwan (2004;131),Baitul Maal Wattamwil (BMT)memiliki fungsi sebagai berikut:

1. Mengidentifikasi,memobilasi,mengorga nisasikan, mendorong dan mengembangkan potensi serta kemampuan potensi ekonomi anggotanya dan daerah kerjanya

2. Meningkatkan kualitas Sumber Daya Manusia anggota menjadi lebih profesional dan islami dalam menghadapi persaingan global.

3. Menggalang dan memobilisasi potensi masyarakat dalam rangka meningkatkan kesejahteraan anggota.
4. Menjadi perantara keuangan untuk dana-dana sosial seperti Zakat, Infaq, Sadaqah, Wakaf dan hibah

5. Menjadi perantara keuangan antara pemilik dana sebagai pemodal dan penyimpan dengan pengguna dana untuk mengembangkan usaha produktif.

Adapun peranan dari Baitul Maal Wattamwil (BMT) sebagai berikut (Soedarsono,2008;304)

1. Menjauhkan masyarakat dari praktek ekonomi ribawi dan aktif melakukan sosialisasi kepada masyarakat berkaitan dengan arti pentingnya sistem ekonomi islam.

2. Melakukan pembinaan dan pendanaan bagi usaha kecil, seperti menjalankan fungsi sebagai pendamping, penyuluh, pengawas terhadap usaha-usaha nasabah.

3. Melepaskan ketergantungan masyarakat pada rentenir dengan memberikan pelayanan dengan mpenyediaan dana setiap saat dan membuat birokrasi yang sederhana.

4. Menjaga keadilan ekonomi masyarakat dengan distribusi yang merata.

\section{Prinsip-prinsip Utama dari Baitul Maal Wattamwil (BMT)}

Terdapat beberapa prinsip-prinsip utama yang dimiliki oleh Baitul Maal Wattamwil (BMT) yaitu, (Ridwan,2004;130) :

1. Keimanan dan ketaqwaan kepada Allah SWT dengan mengimplementasikan prinsip-prinsip syariah dan muamalat islam ke dalam kehidupan nyata.

2. Keterpaduan, adanya nilai-nilai spiritual dan moral yang menggerakkan etika bisnis yang adil dan berakhlak mulia.

3. Kekeluargaan, mengutamakan kepentingan bersama diatas kepentingan pribadi khususnya pengelola pada setiap tingkatan, pengurus dan anggotanya sehingga akan tumbuh rasa kekeluargaan

4. Kebersamaan, kesatuan pola pikir, sikap dan cita-cita antar semua elemen 
yang ada pada Baitul Maal Wattamwil (BMT) seperti pengelola dan pengurus harus memiliki kesatuan visi untuk memperbaiki kondisi ekonomi dan sosial.

5. Kemandirian, mandiri diatas semua golongan politik dan tidak tergantung dengan dana-dana pinjaman dan bantuan tetapi proaktif dalam menggalang dana masyarakat sebanyak-banyaknya.

6. Profesionalisme, semangat kerja yang tinggi yang dilandasi dengan dasar keimanan yang berorientasi pada kehidupan dunia dan akhirat.

7. Istiqomah, adanya konsistensi, keberlanjutan tanpa henti dan putus asa dalam mencapai tujuan yang digariskan syariat.

\section{Kemiskinan}

Kemiskinan memiliki kaitan erat dengan pemerataan pendapatan, kemiskinan muncul akibat ketidakmampuan suatu daerah tertangani dengan baik sehingga menjadi terisolasi dengan adanya daerah yang harus menampung tenaga kerja yang melimpah sedangkan produktivitasnya rendah sehingga terjadi ketidakseimbangan produksi akibatnya daerah tersebut tidak dapat menikmati pembangunan.

\section{Konsep Kemiskinan}

Kemiskinan diartikan sebagai ketidakmampuan untuk memenuhi standar hidup minimum,kemiskinan biasanya diukur dengan tingkat pendapatan.

kemiskinan dibagi menjadi dua bagian;

a. kemiskinan absolut, diartikan sebagai jumlah penduduk yg hidup dibawah garis kemiskinan yg tidak dapat memenuhi kebutuhan dasarnya seperti pangan, sandang, perumahan, kesehatan, pendidikan dan kebutuhan hidup layak lainnya. b. kemiskinan relatif, diartikan sebagai keadaan perbandingan antar kelompok masyarakat dengan pendapatan yang sudah berada diatas garis kemiskinan.

Sedangkan menurut Usman (1998) dalam Ridwan $(2004,5)$ menyebutkan konsep kemiskinan lebih dekat kepada kemiskinan subjektif, di mana kemiskinan didasarkan kepada perasaan kelompok atau orang yang miskin itu sendiri artinya kelompok yang menurut ukuran kita miskin namun menurut perasaan tidak miskin atau kelompok yang menurut standar hidup layak tergolong tidak layak tetapi perasaannya mengatakan layak dan begitupun sebaliknya.

\section{Pandangan islam tentang kemiskinan}

Islam selalu mengajarkan umatnya untuk selalu bekerja keras dalam segala usaha atuu aktivitas di dunia ini agar tidak terjerumus kepada jurang kemiskinan karena islam melarang umatnya menjadi orang miskin, di mana kemiskinan akan mendekati kepada kekufuran. Kemiskinan akan membawa seseorang untuk cenderung berbuat yang diharamkan.

Islam memberikan aturan cara mencari harta serta menganjurkan kepada pemiliknya untuk berusaha membantu sesama, sehingga islam menolak pahampaham ekstrim yang berkaitan dengan kemiskinan, paham-paham tersebut antara lain (Ridwan (2004,11-16).

1. Islam menolak paham yang mensucikan kemiskinan

Penolakan islam tidak saja pada pandangan yang mensucikan kemiskinan tetapi juga termasuk paham zuhud yang telah terpengaruh dengan budaya dari luar islam seperti pikiran manuisme persi, sufiisme hindu, kerahiban nasrani yang tidak satupun ayat dalam Al-Quran atau hadis nabi yang mensucikan kemiskinan.

2. Islam menolak pandangan jabbariah (Totalitas) 
Islam menolak pandangan ini karena pandangan ini mengarah pada kepasrahan total. Menurut paham ini kemiskinan sudah menjadi takdir, tidak satupun orang yang dapat merubahnya. Pandangan ini juga menganggap manusia tidak perlu bersusah payah mengubah nasibnya karena nasib memang sudah ditentukan. Penolakan islam terhadap paham ini adalah setiap orang tidak pernah tahu nasibnya dikemudian hari, manusia boleh merencanakan kehidupan serta berusaha keras dan islam mengajak umatnya untuk merubah nasibnya dari kondisi yang kurang baik menjadi lebih baik.

3. Islam menolak paham yang menggantungkan pada kesalehan pribadi dan sedekah suka rela.

Islam menganjurkan umatnya untuk saling tolong menolong, membantu sesama, menyantuni fakir miskin, memelihara anak yatim tetapi islam menolak dari segi motivasinya. Karena menolong menurut pandangan ini semata-mata karena kesadaran individu, tidak ada ukuran yang jelas dan ketegasan tanggung jawab orang yang ditolong. Islam menilai pandangan ini tiak membawa kemajuan karena orang miskin akan senantiasa tergantung dari belas kasihan orang kaya.

4. Islam menolak pandangan kapitalisme Islam menolak pandangan yang mengatakan bahwa harta adalah milik hakiki empunya, di mana mereka bebas membelanjakannya, orang tidak berhak sama sekali terhadap harta orang lain. Pandangan ini sama dengan kisah Qorun yang menyebutkan seluruh hartanya adalah hasil kerja kerasnya sendiri tanpa adanya campur tangan tuhan.

Islam menolak pandangan ini karena pemilik mutlak dari harta benda adalah Allah SWT, manusia hanya diberikan amanah untuk menjaganya dan suatu saat nanti akan dimintai pertanggungjawaban terhadap harta yang telah digunakannya.

5. Islam menolak paham Marxisme Menurut paham ini kemiskinan hanya akan dapat diatasi dengan jalan menghapuskan hak individu dan menjadikannya hak bersama. Pandangan ini bertentangan dengan islam, kerana islam menghargai hakhak individu dan sosial.

\section{Kaitan antara lembaga keuangan mikro dengan Kemiskinan}

Fungsi intermediasi di dalam perekonomian dijalankan oleh lembaga keuangan mikro, dimana uang (kredit/pembiayaan) menjadi darahnya perekonomian, terutama akses modal kepada masyarakat miskin sangat dibutuhkan untuk mengurangi kemiskinan.

Pengentasan kemiskinan dilakukan dengan berbagai sarana dan program baik yang bersifat langsung maupun yang bersifat tidak langsung seperti melalui pemberdayaan usaha produktif melalui pinjaman dalam bentuk kredit mikro.

Kaitan antara pengentasan kemiskinan dengan pemberdayaan kredit mikro merupakan pintu masuk bagi orang yang akan menjadi pengusaha pemula agar mereka mendapat kesempatan untuk mengembangkan ide dan kreatifitas usahanya sehingga diharapkan akan memberikan pendapatan bagi masyarakat sekitar.

\section{Jenis Penelitian}

\section{METODE PENELITIAN}

Jenis penelitian yang digunakan dalam penelitian ini adalah penelitian deskriptif ,yaitu penelitian yang bertujuan untuk mengumpulkan data untuk diuji hipotesis atau menjawab pertanyaan mengenai status terakhir dari subjek penelitian yang berkaitan dengan penilaian sikap atau 
pendapat terhadap individu, organisasi, keadaan, ataupun prosedur (Kuncoro,2003;8).

\section{Jenis dan Sumber Data}

\section{Jenis data}

Jenis data dalam penelitian ini adalah :

a. Data kuantitatif yaitu data yang diperlukan dalam penelitian yang berupa angka angka yang dapat diukur besarnya dan dapat dihitung secara pasti.

b. Data kualitatif yaitu data yang diperlukan dalam penelitian ini berupa keterangan dan kebijakan pengembangan yang berkaitan dengan pengembangan dan strategi dalam mengurangi kemiskinan di Nusa Tenggara Barat.

\section{Sumber data}

a. Data primer adalah data yang diperoleh secara langsung dari responden yang dipilih oleh peneliti dengan pertimbangan tertentu yang dapat memberikan informasi atau keterangan yang diperlukan. Data primer diperoleh dari wawancara dengan stakeholder yang ada di dalam lembaga keuangan mikro syariah (Baitul Maal Wattamwil)

b Data sekunder, adalah data yang diperoleh dari lembaga keuanganmikro syariah, lembaga Pusat
Inkubasi bisnis (PINBUK) dan Bank indonesia.

\section{Teknik dan alat pengumpul data}

Teknik yang digunakan dalam mengumpulkan data dalam penelitian ini adalah

1. Dokumentasi yaitu pengumpulan data berupa catatan-catatan yang tersedia pada lembaga terkait

2. Study kepustakaan, yaitu pengumpulan data dengan cara penelahaan kepustakaan dengan obyek- obyek yang akan dibahas dan bahan bacaan yang berhubungan dengan masalah yang diteliti.

3. Wawancara,yaitu teknik pengumpulan data dengan cara tanya jawab langsung dengan lembaga keuangan mikro dan lembaga keuangan terkait.

\section{Prosedur Analisis}

Teknik analisis yang digunakan adalah analisis SWOT (Strength, Weakness, Opportunity, Treath) untuk mengetahui strategi kebijakan pengembangan Baitul Maal Wattamwil (BMT) dalam mengurangi kemiskinan.

Analisis SWOT yang digunakan dalam penelitian ini adalah untuk membandingkan antara faktor eksternal peluang (opportunities) dan ancaman (threats) dengan faktor internal kekuatan (strengths) dan kelemahan (weaknesses).

Gambar 1 Matrik SWOT

\begin{tabular}{|l|l|l|}
\hline \multicolumn{1}{|c|}{ IFAS } & $\begin{array}{l}\text { STRENGTHS (S) } \\
\text { Tentukan 5-30 kekuatan internal }\end{array}$ & $\begin{array}{l}\text { WEAKNESSES (W) } \\
\text { Tentukan 5-30 } \\
\text { kelemahan internal }\end{array}$ \\
\hline $\begin{array}{l}\text { OPPORTUNITIES (O) } \\
\text { Tentukan 5-30 peluang } \\
\text { eksternal }\end{array}$ & $\begin{array}{l}\text { STRATEGI SO } \\
\text { Ciptakan strategi yang menggunakan } \\
\text { kekuatan untuk memanfaatkan } \\
\text { peluang }\end{array}$ & $\begin{array}{l}\text { STRATEGI WO } \\
\text { Ciptakan strategi yang } \\
\text { meminimalkan } \\
\text { kelemahan untuk } \\
\text { memanfaatkan peluang }\end{array}$ \\
\hline $\begin{array}{l}\text { THREATS (T) } \\
\text { Tentukan 5-30 } \\
\text { ancaman eksternal }\end{array}$ & $\begin{array}{l}\text { STRATEGI ST } \\
\text { Ciptakan strategi yang menggunakan } \\
\text { kekuatan untuk mengatasi ancaman }\end{array}$ & $\begin{array}{l}\text { STRATEGI WT } \\
\text { Ciptakan strategi yang } \\
\text { meminimalkan kelemahan dan } \\
\text { menghindari ancaman }\end{array}$ \\
\hline
\end{tabular}

Sumber: (Rangkuti, 2002:31) 
Analisis Penelitian

\section{ANALISIS DAN PEMBAHASAN}

1. Analisis SWOT Lingkungan Internal Baitul Maal Wattamwil (BMT)

Tabel.2 Analisis SWOT factor internal (Kekuatan) BMT

\begin{tabular}{|r|l|r|r|r|}
\hline No & Faktor internal & \multicolumn{1}{|l|}{ Bobot } & \multicolumn{1}{l|}{ Rating } & \multicolumn{1}{l|}{ Skor } \\
\hline & KEKUATAN & & & \\
\hline 1 & Lokasi yg strategis & 0.08 & 3.50 & 0.28 \\
\hline 2 & Strategi jemput bola & 0.06 & 3.25 & 0.20 \\
\hline 3 & Pendidikan pengurus memadai & 0.06 & 2.50 & 0.15 \\
\hline & Solidaritas yg tinggi antara & & & \\
4 & pengurus dan pengelola & 0.07 & 2.25 & 0.16 \\
\hline 5 & Memiliki kantor sendiri & 0.08 & 3.30 & 0.26 \\
\hline & Total Bobot kekuatan & $\mathbf{0 . 3 5}$ & $\mathbf{1 4 . 8}$ & $\mathbf{1 . 0 5}$ \\
\hline
\end{tabular}

Dari tabel 1 analisis SWOT penelitian dengan melihat factor internal Baitul Maal Wattamwil (BMT) dengan menggunakan 5 Faktor seperti Faktor lokasi yang strategis, strategi jemput bola, pendidikan pengurus memadai, solidaritas yg tinggi antara pengurus dan pengelola serta memiliki kantor sendiri, dimana total keseluruhan nilai skor dari hasil pembobotan analisis SWOT adalah 1,05. Faktor strategi internal (kekuatan) yang memiliki nilai paling tinggi adalah lokasi yang strategis dengan skor tertinggi 0,28, artinya Baitul Maal Wattamwil (BMT) di Nusa Tenggara Barat harus memiliki lokasi yang strategis yaitu lokasi yang dekat dengan nasabah, dekat dengan pusat ekonomi, dekat dengan pasar agar Baitul Maal Wattamwil (BMT) di Nusa Tenggara Barat dapat berkembang untuk dapat memberikan bantuan permodalan usaha kepada masyarakat miskin atau masyarakat menengah kebawah sehingga kemiskinan dapat berkurang.
Faktor strategi internal (kekuatan) yang memiliki nilai paling tinggi kedua adalah BMT harus memiliki kantor sendiri dengan skor 0,26 artinya Baitul Maal Wattamwil (BMT) di Nusa Tenggara Barat harus memiliki kantor sendiri agar dapat mempermudah pelayanan kepada masyarakat dan nasabah, selain itu juga BMT yang memiliki kantor sendiri akan lebih dipercaya oleh nasabah atau masyarakat karena dapat menunjukkan eksistensi BMT itu sendiri di mata nasabah atau masyarakat dan tentunya untuk lebih memudahkan operasional Baitul Maal Wattamwil (BMT) dalam kegiatan pelayanan kepada nasabah atau masyarakat.

Untuk analisis SWOT factor internal (Kekuatan) Baitul Maal Wattamwil (BMT) di Nusa Tenggara Barat terlihat bahwa skor seluruh bobot kekuatan sebesar 1,05 artinya strategi internal yang diterapkan masih lemah karena nilai skor bobot kurang dari 2,5.

2. Analisis SWOT Lingkungan internal Baitul Maal Wattamwil (BMT)

Tabel 2 Analisis SWOT faktor internal (Kelemahan) BMT

\begin{tabular}{|r|l|r|r|r|}
\hline No & Faktor internal & \multicolumn{1}{|l|}{ Bobot } & \multicolumn{1}{|l|}{ Rating } & \multicolumn{1}{l|}{ Skor } \\
\hline & KELEMAHAN & & & \\
\hline 1 & Kurangnya pemanfaatan TI & 0.04 & 2.50 & 0.10 \\
\hline 2 & Tidak adanya ATM & 0.06 & 1.25 & 0.08 \\
\hline 3 & Kurangnya sosialisasi & 0.05 & 2.50 & 0.13 \\
\hline 4 & Kurangnya promosi & 0.04 & 2.55 & 0.10 \\
\hline 5 & Belum bisa melayani haji & 0.03 & 1.20 & 0.04 \\
\hline
\end{tabular}


Dari tabel 2 analisis SWOT penelitian dengan melihat factor internal Baitul Maal Wattamwil (BMT) dengan menggunakan 5 Faktor seperti Faktor Kurangnya pemanfaatan TI, Tidak adanya ATM, Kurangnya sosialisasi, Kurangnya promosi, Belum bisa melayani haji, dimana total keseluruhan nilai skor dari hasil pembobotan analisis SWOT adalah 0,44. Faktor strategi internal (Kelemahan) yang memiliki nilai paling tinggi adalah Kurangnya sosialisasi dengan skor tertinggi 0,13 artinya Baitul Maal Wattamwil (BMT) di Nusa Tenggara Barat harus melakukan sosialisasi dan promosi yang cukup gencar melalui pondok pesantren dan masjid-masjid agar masyarakat atau nasabah dapat menggunakan atau memanfaatkan produk BMT dengan baik sehingga tujuan BMT untuk memberikan kemaslahatan bagi masyarakat dapat tercapai.

3. Analisis SWOT Lingkungan eksternal Baitul Maal Wattamwil (BMT)

Tabel 3 Analisis SWOT factor Eksternal (Peluang) BMT

\begin{tabular}{|r|l|r|r|r|}
\hline No & Faktor eksternal & \multicolumn{1}{|l|}{ Bobot } & \multicolumn{1}{|l|}{ Rating } & \multicolumn{1}{l|}{ Skor } \\
\hline & PELUANG & & & 0.18 \\
\hline 1 & Potensi pasar BMT yg luas & 0.06 & 3.00 & 0.18 \\
\hline 2 & Dekat dg pusat ekonomi & 0.05 & 3.65 & 0.11 \\
\hline 3 & BMT memberdayakan UMKM & 0.04 & 2.80 & 0.07 \\
\hline 4 & Sistem bagi hasil (syariah) BMT & 0.03 & 2.45 & \\
\hline & BMT memberdayakan masyarakat & & & 0.22 \\
\hline 5 & miskin & 0.07 & 3.15 & $\mathbf{0 . 7 7}$ \\
\hline & Total Bobot kekuatan & $\mathbf{0 . 2 5}$ & $\mathbf{1 5 . 0 5}$ & \\
\hline
\end{tabular}

Sumber : data diolah

Dari tabel 3 analisis SWOT penelitian dengan melihat factor eksternal Baitul Maal Wattamwil (BMT) dengan menggunakan 5 Faktor seperti Faktor Potensi pasar BMT yg luas, Dekat dg pusat ekonomi, BMT memberdayakan UMKM, Sistem bagi hasil (syariah) BMT, BMT memberdayakan masyarakat miskin dimana total keseluruhan nilai skor dari hasil pembobotan analisis SWOT adalah 0,77. Faktor strategi Eksternal (Peluang) yang memiliki nilai paling tinggi adalah
Faktor strategi internal (Kelemahan) yang memiliki nilai paling tinggi kedua adalah kurangnya pemanfaatan IT (teknologi informasi) dengan skor 0,10 artinya Baitul Maal Wattamwil (BMT) di Nusa Tenggara Barat belum menggunakan dan memanfaatkan teknologi dengan baik agar pelayanan yang di berikan kepada nasabah atau masyarakat dapat maksimal sehingga BMT di Nusa Tenggara Barat masih tertinggal dengan lembaga keuangan lainnya seperti perbankan syariah atau lembaga keuangan lainnya yang sejenis.

Untuk analisis SWOT factor internal (Kelemahan) Baitul Maal Wattamwil (BMT) di Nusa Tenggara Barat terlihat bahwa skor seluruh bobot kelemahan sebesar 0,44 artinya strategi internal yang diterapkan masih lemah karena nilai skor bobot kurang dari 2,5. 
Faktor strategi Eksternal (Peluang) yang memiliki nilai paling tinggi kedua adalah Potensi pasar BMT yg luas dengan skor 0,18 artinya Baitul Maal Wattamwil (BMT) di Nusa Tenggara Barat memiliki potensi pasar yang cukup besar untuk dilayani dan diberikan bantuan permodalan melalui pembiayaan karena jumlah penduduk NUSA TENGGARA BARAT yang mayoritas penduduknya muslim atau beragama islam sehingga tinggal diberikan pemahaman dan sosialisasi kepada masyarakah atau nasabah agar dapat memahami seluk beluk atau segala hal yang berkaitan dengan Baitul Maal Wattamwil (BMT).

Untuk analisis SWOT factor Eksternal (Peluang) Baitul Maal Wattamwil (BMT) di Nusa Tenggara Barat terlihat bahwa skor seluruh bobot peluang sebesar 0,77 artinya strategi eksternal yang diterapkan masih lemah karena nilai skor bobot kurang dari 2,5.

4. Analisis SWOT Lingkungan eksternal Baitul Maal Wattamwil (BMT)

Tabel 4 Analisis SWOT factor Eksternal (Ancaman) BMT

\begin{tabular}{|r|l|r|r|r|}
\hline No & Faktor eksternal & Bobot & \multicolumn{1}{|l|}{ Rating } & \multicolumn{1}{l|}{ Skor } \\
\hline & ANCAMAN & & & \\
\hline 1 & Kurangnya modal BMT & 0.03 & 2.70 & 0.08 \\
\hline 2 & Kualitas SDI masih kurang & 0.05 & 1.70 & 0.09 \\
\hline 3 & Adanya KUR & 0.04 & 2.30 & 0.09 \\
\hline 4 & Kurangnya penggunaan TI & 0.03 & 2.35 & 0.07 \\
\hline & Bank syariah yg menggarap pasar & & & \\
5 & mikro & 0.06 & 3.48 & 0.21 \\
\hline & Total Bobot kelemahan & $\mathbf{0 . 2 1}$ & $\mathbf{1 2 . 5 3}$ & $\mathbf{0 . 5 4}$ \\
\hline
\end{tabular}

Sumber : data diolah

Dari tabel 4 analisis SWOT penelitian dengan melihat factor eksternal Baitul Maal Wattamwil (BMT) dengan menggunakan 5 Faktor seperti Faktor Kurangnya modal BMT, Kualitas SDI masih kurang, Adanya KUR, Kurangnya penggunaan $\mathrm{Tl}$, Bank syariah yg menggarap pasar mikro dimana total keseluruhan nilai skor dari hasil pembobotan analisis SWOT adalah 0,54. Faktor strategi Eksternal (Ancaman) yang memiliki nilai paling tinggi adalah Bank syariah yg menggarap pasar mikro dengan skor tertinggi 0,21 artinya Baitul Maal Wattamwil (BMT) di Nusa Tenggara Barat memiliki pesaing yang cukup berat yaitu dari bank syariah yang mulai menggarap sector mikro atau nasabah mikro kecil yang selama ini menjadi pasar yang cukup potensial bagi BMT di Nusa Tenggara Barat, belum lagi adanya pesaing dari bank konvesional yang selama ini menggarap sector mikro kecil seperti bank BRI konvesional yang telah lebih dahulu menggarap sector mikro dan cukup berpengalaman dalam bidang ini sehingga factor ini menjadi ancaman yang cukup serius bagi BMT di Nusa Tenggara Barat.

Faktor strategi Eksternal (ancaman) yang memiliki nilai paling tinggi kedua adalah adanya KUR (Kredit usaha rakyat) artinya Baitul Maal Wattamwil (BMT) di Nusa Tenggara Barat memiliki ancaman dari pesaing perbankan konvesional yang memberikan fasilitas KUR kepada nasabah mikro kecil sehingga pangsa pasar BMT di Nusa tengara barat semakin berkurang dan persaingan untuk mendapatkan nasabah atau anggota BMT semakin ketat. Untuk analisis SWOT factor Eksternal (ancaman) Baitul Maal Wattamwil (BMT) di Nusa Tenggara Barat terlihat bahwa skor seluruh bobot ancaman sebesar 0,54 artinya strategi eksternal yang diterapkan 
masih lemah karena nilai skor bobot kurang dari 2,5.

\section{Pembahasan}

Dari analisis SWOT diatas terlihat bahwa Faktor strategi internal (Kekuatan) yang memiliki nilai paling tinggi adalah Kurangnya sosialisasi dengan skor tertinggi 0,13 artinya Baitul Maal Wattamwil (BMT) di Nusa Tenggara Barat harus melakukan sosialisasi dan promosi yang cukup gencar melalui pondok pesantren dan masjid-masjid agar masyarakat atau nasabah dapat menggunakan atau memanfaatkan produk BMT dengan baik sehingga tujuan BMT untuk memberikan kemaslahatan bagi masyarakat dapat tercapai. Faktor strategi internal (Kelemahan) yang memiliki nilai paling tinggi adalah Kurangnya sosialisasi dengan skor tertinggi 0,13 artinya Baitul Maal Wattamwil (BMT) di Nusa Tenggara Barat harus melakukan sosialisasi dan promosi yang cukup gencar melalui pondok pesantren dan masjid-masjid agar masyarakat atau nasabah dapat menggunakan atau memanfaatkan produk BMT dengan baik sehingga tujuan BMT untuk memberikan kemaslahatan bagi masyarakat dapat tercapai. Faktor strategi Eksternal (Peluang) yang memiliki nilai paling tinggi adalah BMT memberdayakan masyarakat miskin dengan skor tertinggi 0,22, artinya Baitul Maal Wattamwil (BMT) di Nusa Tenggara Barat dapat berkembang dengan baik karena memiliki peluang untuk pemberdayaan masyarakat di Nusa Tenggara Barat melalui bantuan permodalan dan pembiayaan kepada sector usaha mikro kecil sehingga akan dapat memberikan peluang juga untuk mengurangi kemiskinan di Nusa Tenggara Barat. Faktor strategi Eksternal (Ancaman) yang memiliki nilai paling tinggi adalah Bank syariah yg menggarap pasar mikro dengan skor tertinggi 0,21 artinya Baitul
Maal Wattamwil (BMT) di Nusa Tenggara Barat memiliki pesaing yang cukup berat yaitu dari bank syariah yang mulai menggarap sector mikro atau nasabah mikro kecil yang selama ini menjadi pasar yang cukup potensial bagi BMT di Nusa Tenggara Barat, belum lagi adanya pesaing dari bank konvesional yang selama ini menggarap sector mikro kecil seperti bank BRI konvesional yang telah lebih dahulu menggarap sector mikro dan cukup berpengalaman dalam bidang ini sehingga factor ini menjadi ancaman yang cukup serius bagi BMT di Nusa Tenggara Barat. Dari hasil analisis SWOT diatas juga dapat dirumuskan strategi pengembangan Baitul Maal Wattamwil (BMT) di Nusa Tenggara Barat sebagai berikut ;

1. Melakukan sosialisasi tentang konsep keuangan mikro syariah (BMT) ke masyarakat.

2. Pelatihan ke pada pegawai BMT berkaitan dgn pemasaran dan pelayanan nasabah

3. Menambah teknologi pendukung untuk operasional BMT

4. Membuat webside dan mempromosikan produk BMT

5. Membangun relationship dengan masyarakat sekitar

6. Turun ke pasar-pasar / jemput bola untuk mencari nasabah/anggota BMT

\section{KESIMPULAN}

1. Faktor pendukung dapat dilihat dari kekuatan dan peluang yang dimiliki oleh BMT di Nusa Tenggara Barat yaitu Baitul Maal Wattamwil (BMT) di Nusa Tenggara Barat harus memiliki lokasi yang strategis yaitu lokasi yang dekat dengan nasabah, dekat dengan pusat ekonomi, dekat dengan pasar agar Baitul Maal Wattamwil (BMT) di Nusa Tenggara Barat dapat berkembang untuk dapat memberikan bantuan permodalan usaha kepada masyarakat miskin atau masyarakat menengah kebawah sehingga kemiskinan di Nusa 
Tenggara Barat dapat berkurang dan BMT memberdayakan masyarakat miskin artinya Baitul Maal Wattamwil (BMT) di Nusa Tenggara Barat dapat berkembang dengan baik karena memiliki peluang untuk pemberdayaan masyarakat di Nusa Tenggara Barat melalui bantuan permodalan dan pembiayaan kepada sector usaha mikro kecil sehingga akan dapat memberikan peluang juga untuk mengurangi kemiskinan di Nusa Tenggara Barat.

2. Faktor Penghambat dapat dilihat dari kelemahan dan ancaman yang dimiliki oleh BMT di Nusa Tenggara Barat yaitu Kurangnya sosialisasi artinya Baitul Maal Wattamwil (BMT) di Nusa Tenggara Barat harus melakukan sosialisasi dan promosi yang cukup gencar melalui pondok pesantren dan masjid-masjid agar masyarakat atau nasabah dapat menggunakan atau memanfaatkan produk BMT dengan baik sehingga tujuan BMT untuk memberikan kemaslahatan bagi masyarakat dapat tercapai dan Bank syariah yg menggarap pasar mikro artinya Baitul Maal Wattamwil (BMT) di Nusa Tenggara Barat memiliki pesaing yang cukup berat yaitu dari bank syariah yang mulai menggarap sector mikro atau nasabah mikro kecil yang selama ini menjadi pasar yang cukup potensial bagi BMT di Nusa Tenggara Barat.

3. Strategi kebijakan BMT yaitu dalam menghadapi ancaman BMT di Nusa Tenggara Barat harus terus menerus mengembangkan diri secara kreatif,inovatif,dan selalu memiliki perbaikan dalam pelayanan kepada nasabah BMT, pemerintah juga harus memberikan fasilitas kepada BMT terutama bantuan permodalan dan fasilitas-fasilitas agar BMT dapat berkembang dengan baik.

\section{DAFTAR PUSTAKA}

Antonio,Syafi'i.2001.Bank Syariah "Dari teori ke praktek".Gema Insani Press.Jakarta

Abu Umar Faruq Ahmad and A. B. Rafique Ahmad. Islamic Microfinance: A Case Study of Australia. Journal of Islamic Econ 60 omics, Banking and Finance

Asyraf Wajdi Dusuki (2007). Banking for the Poor: The Role of Islamic Banking in Microfinance Initiatives. Proceedings of the 2nd Islamic Conference 2007 (iECONS2007) organized by Faculty of Economics and Muamalat, Islamic Science University of Malaysia.

Kuncoro,Mudrajad.2003. Metode Riset Untuk Ekonomi dan Bisnis.Erlangga.Jakarta

Muhammad.2002. Manajemen bank syariah. UPP AMP YKPN.Jogjakarta.

Sudarsono,Heri.2008.Bank dan Lembaga Keuangan Syariah"Deskripsi dan Ilustrasi". Edisi 3. Ekonisia.Jogjakarta.

Syeda Shehrbano Kazim dan Syed Eisar Haider .2012. Islamic microfinanceModelsAnd their viabilityIn pakistan. Pakistan Microfinance Network No.15 Juni 2012 
92 | Irwan Suriadi/Peluang dan Tantangan Lembaga Keuangan...

Nurkholis (2009).The contribution of islamic microfinance institution in Increasing social welfare in indonesia (a case study of bmt's role at pakem market micro Traders yogyakarta) .Islamic Economic Department, Faculty of Islamic Studies, Islamic University of Indonesia, Yogyakarta, Indonesia.

Ridwan,Muhammad.2004.Manajemen Baitul Maal Wattamwil.UII Press.Jakarta

Rangkuti, Freddy. 2002. Analisis SWOT Teknik Membedah Kasus Bisnis, PT. Gramedia Pustaka Utama: Jakarta.

Wiloejo Wirjo Wiyono (2005). Pemberdayaan lembaga keuangan mikro sebagai salah satu pilar sistem keuangan nasional : upaya konkrit memutus mata rantai kemiskinan. Jurnal kajian ekonomi dan keuangan edisi khusus Desember 2005.Jakarta 